\title{
Effects of sildenafil on the viability of random skin flaps ${ }^{1}$
}

\section{Os efeitos do sildenafil na viabilidade de retalhos cutâneos randômicos}

\author{
Sumara Marques Barral', Ivana Duval Araujo", Paula Vieira Teixeira Vidigal ${ }^{\mathrm{III}}$, Cláudio Alvarenga Campos Mayrink ${ }^{\mathrm{IV}}$, Adriana \\ Duval Araujov", Paulo Roberto da Costa ${ }^{\mathrm{VI}}$ \\ ${ }^{1}$ Research performed at the Animal Experimentation Laboratory, Department of Surgery, Faculty of Medicine, Federal University of Minas Gerais \\ (UFMG), Belo Horizonte-MG, Brazil. Part of the dissertation of the first author. Tutor: Ivana Duval Araujo, Postgraduate Program of Sciences \\ Applied to Surgery and Ophthalmology.

\footnotetext{
${ }^{I}$ Master, Volunteer Faculty, Department of Surgery, UFMG, Belo Horizonte-MG, Brazil. Responsible for delineation of the project, execution of the study and publication of the results.

${ }^{\text {II }} \mathrm{PhD}$, Associate Professor, Department of Surgery, UFMG, Belo Horizonte-MG, Brazil. Responsible for the interpretation of the data and the critical revision of the study.

III PhD, Associate Professor, Department of Pathology, UFMG, Belo Horizonte-MG, Brazil. Histological analyses and data discussion.

${ }^{\text {IV }}$ Graduate student, School of Medicine, UFMG, Belo Horizonte-MG, Brazil. Helped in surgical procedures.

${ }^{\vee}$ Architect. Responsible for measurement and mathematic determination of the areas of necrosis, ischemia and tissular viability.

${ }^{\mathrm{VI}} \mathrm{PhD}$, Associate Professor, Morphology Department, UFMG, Belo Horizonte-MG, Brazil. Critical revision.
}

\begin{abstract}
Purpose: To assess the viability of McFarlane skin flaps in rats with administration of sildenafil. Methods: Twenty Wistar rats were distributed into two groups: Control (dorsal skin flap, subdermal application of saline solution at $0.9 \%$ ) and Study (dorsal skin flap, subdermal application of sildenafil). Seven days after the surgery, flaps were photographed and graphically rendered. Then, they were analyzed with AutoCAD software. Three biopsies (proximal, medial and distal) of each flap were collected for histological analysis. Results: Macroscopic analysis showed that animals of the study group had greater necrotic areas ( $\mathrm{p}=0.003)$ in the dorsal skin flaps. Additionally, histological analysis of the distal third of these flaps showed a tendency to less granulated tissue formation in animals treated with sildenafil. Conclusion: Sildenafil subdermally was associated with lower viability of the random skin flap in rats.

Key words: Wound Healing. Surgical Flaps. Cyclic GMP. Nitric Oxide. Rats.

\section{RESUMO}

Objetivo: Avaliar a viabilidade de retalhos cutâneos de ratos à McFarlane após a administração de sildenafil. Métodos: Vinte ratos Wistar foram distribuídos em dois grupos: Controle (confecção do retalho cutâneo dorsal, aplicação subdérmica de solução salina a $0,9 \%$ ) e Estudo (confecção do retalho cutâneo dorsal, aplicação subdérmica de sildenafil). Sete dias após a operação, os retalhos foram fotografados e representados graficamente, para serem analisados com o programa AutoCad. Três biópsias (cranial, média e caudal) foram coletadas de cada retalho, para análise histológica. Resultados: A análise macroscópica evidenciou que os animais do grupo Estudo apresentaram maiores áreas de necrose $(\mathrm{p}=0,003)$ nos retalhos cutâneos dorsais. Além disso, a análise histológica dos terços distais dos retalhos mostrou uma tendência à formação de menos tecido de granulação nos animais que receberam o sildenafil. Conclusão: O sildenafil subdérmico esteve associado com uma pior viabilidade tecidual dos retalhos cutâneos dorsais de ratos.

Descritores: Cicatrização de Feridas. Retalhos Cirúrgicos. GMP Cíclico. Óxido Nítrico. Ratos.
\end{abstract}




\section{Introduction}

The viability of skin flaps depends on many factors such as absence of venous congestion and hematoma, appropriate perfusion pressure and attention to surgical principles. The presence of edema, thrombosis or vasospasm, as well as release of free radicals, can result in ischemia and even necrosis, mainly in their distal portions. Associated with these characteristics, the format and dimensions of the flaps are also related to their viability, principally in random flaps, which is often used in reconstructive surgery.

Some auxiliary therapeutic resources were proposed in the attempt to improve flap survival, such as autonomization ${ }^{1}$, intramuscular use of ketorolac ${ }^{2}$, corticosteroids and carnitine ${ }^{3}$, hyperbaric oxygen therapy ${ }^{4}$, pentoxifylline ${ }^{5}$, buflomedil ${ }^{6}$, and even sildenafil isolated or in association with endothelial vascular growth or fibrin glue $\mathrm{e}^{7-11}$. However, response to these systemic treatments may be associated with adverse effects, for example hypotension, amnesia, visual disturbances, migraine and even vascular accidents ${ }^{12}$.

Studies on the effects of nitric oxide synthesis in wounds suggest that sildenafil could increase blood flow in flaps, thus improving survival. Moreover, since platelets have phosphodiesterase type 5 receptors, this medication could act on its activation profile, assisting the wound healing ${ }^{12}$. In this context, sildenafil citrate could be used to improve survival of random skin flaps when used systemically and even topically, so as to minimize adverse effects. In order to evaluate the action of sildenafil in viability of McFarlane ${ }^{13}$ skin flaps of rats we conducted this study.

\section{Methods}

The Ethic Committee in Animal Research (CETEA) of the Federal University of Minas Gerais (UFMG) approved the study, protocol CETEA 094/09. The use of laboratory animals followed the Council for International Organization of Medical Sciences (CIOMS) and the principles of the Brazilian College on Animal Experimentation Twenty adult female Wistar rats, weighing $215 \mathrm{~g}$ to $255 \mathrm{~g}$, were divided into two groups:

Study $(n=10)$ : dorsal skin flap and subdermal application of sildenafil.

Control $(\mathrm{n}=10)$ : dorsal skin flap and subdermal application of saline solution at $0.9 \%$.

Animals were anaesthetized with an $80 \mathrm{mg} / \mathrm{kg}$ ketamine solution (Ketamine Agener 10\%, Agener Uinao), associated with $8 \mathrm{mg} / \mathrm{kg}$ of xylazine (Xylasine 2\%, Calmium, Agener Uniao) intraperitoneally. After antisepsis, rectangular dorsal skin flaps of $3 \times 7 \mathrm{~cm}\left(21 \mathrm{~cm}^{2}\right)$ were performed with their basis tangential to the inferior angles of the scapula, taking as reference a mold made of acetate film. The flap was dissected from the panniculus carnosus and repositioned to the bed by a simple running suture with a 4.0 nylon monofilament (Figure 1).

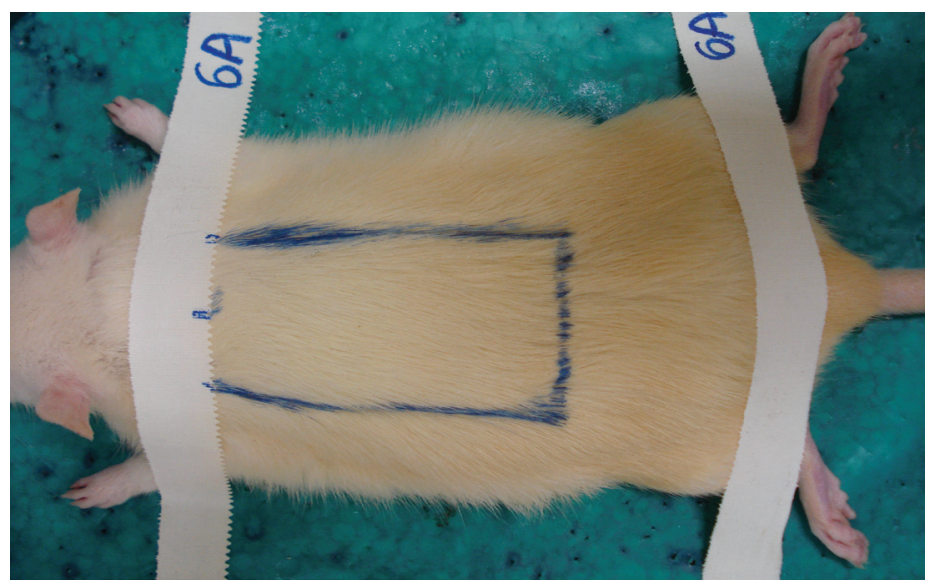

FIGURE 1 - Photography of an animal in ventral decubitus, with the limbs in extension. Demarcation of the dorsal flap, using the inferior angles of the scapula as a reference.

Animals of the study group received sildenafil citrate in an aqueous solution (FarmaVet), administered subdermally (dosage of $0.5 \mathrm{mg} / \mathrm{kg}$ and volume $5 \mathrm{ml} / \mathrm{kg}$ ). Saline solution at $0.9 \%$ (Isofarma Industrial Farmaceutica) was administered in the control group subdermally (volume of $5 \mathrm{ml} / \mathrm{kg}$ ). Substances were administered once daily, immediately after the surgical procedure and 48 hours afterwards. The total volume of sildenafil or saline solution was fractionated and administered in nine points of the flap, following a previously established demarcation through an acetate mold positioned over the animal's back. Previously to administration of the substances, animals were sedated with a solution of ketamine $(40 \mathrm{mg} / \mathrm{kg})$ associated with xylazine $(4 \mathrm{mg} /$ $\mathrm{kg})$, intraperitoneally.

On the seventh day of observation, animals were euthanized by anesthesia overdose. The flaps were graphically represented in a transparent sheet (acetate sheet), by an observer blinded to group assignment. Criteria for classification were based on inspection and palpation. Three regions of the flaps were limited according to its characteristics:

1) Regions of necrosis: characterized by brown and black coloration, and cadaveric consistency to palpation.

2) Regions of ischemia: presenting violet coloration and palpatory malleability.

3) Regions of tissular viability: with usual murine skin 
coloration and texture.

Figures were put on graph paper and digitalized at 600 dpi. The digital file was loaded into AutoCAD Release (Version 13.1, 1995) to plot the perimeters of each flap regions (necrosis, ischemia and tissular viability) with different colors and the respective areas were calculated (Figure 2). A researcher blinded to group assignment conducted this stage of the study. Additionally, the final area of the flap was compared to the initial area to determine tissue contraction. The percentage of each area in relation to the final flap area was also calculated.

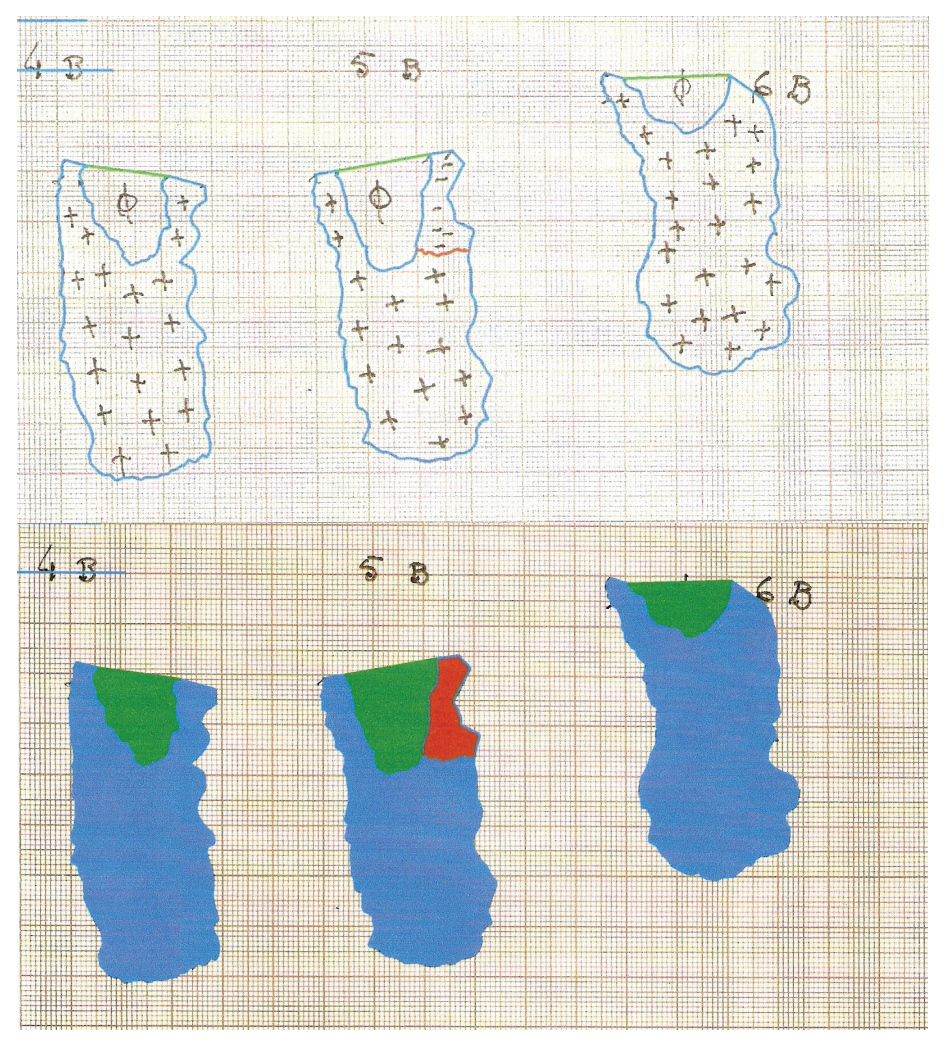

FIGURE 2 - Illustration of the digital files loaded into AutoCAD Release software. Above: Regions of necrosis marked with the signal "+", region of ischemia marked with the signal "-", and regions of tissular viability marked with the signal " $\varnothing$ ". Below: Representation of the regions with different colors to calculate the areas. Regions of necrosis indicated in blue, region of ischemia in red and regions of tissular viability in green.

To collect tissue samples, imaginary lines were designed to divide the flap symmetrically into three parts in the craniocaudal direction, and into left and right halves. In the caudal extremity of each area, a sample of $0.5 \mathrm{~cm} \times 0.5 \mathrm{~cm}$ was collected, touching the medial edge of the right half of the flap (Figure 3).

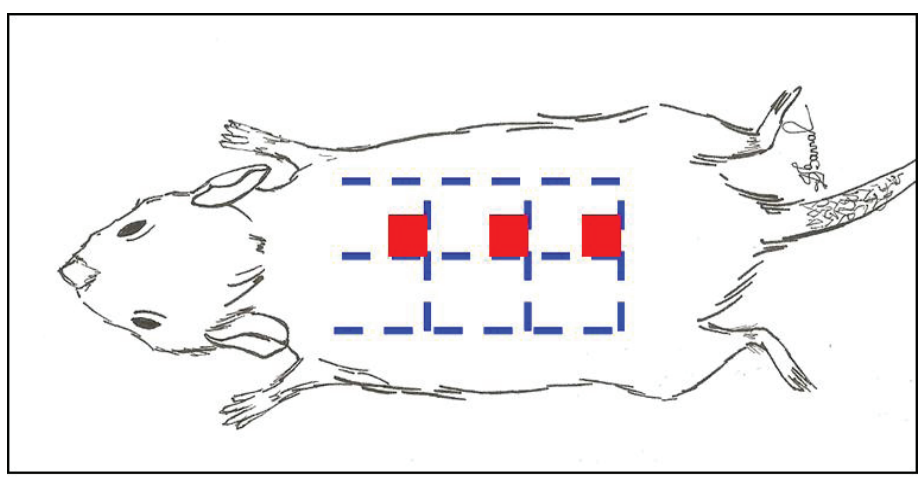

FIGURE 3 - Illustration representing the skin flap divided into three parts in the craniocaudal direction and the three fragments of $0.5 \times 0.5 \mathrm{~cm}$ in the edge of each area, bordering the medial edge of the right half of the flap.

The tissue samples were stained with hematoxyline and eosine, assessed by a pathologist blinded to group assignment and classified into: granulation, granulation associated with necrosis and granulation associated with polymorphonuclears.

For macroscopic data comparison, Mann-Whitney's test and Wilcoxon signed-rank test were used. Histological data were analyzed by Fisher's exact test or Pearson's chi-square test, according to the number of cells with expected value less than five. $\mathrm{P}$ value $<0.05$ was considered significant.

\section{Results}

In absolute values, the necrotic areas in study group were significantly higher than in control group $(p=0.003)$. Means and medians of the necrotic areas, viability, and tissular injury are displayed on Table 1.

TABLE 1 - Areas of tissular viability, necrosis and ischemia in study group (sildenafil subdermic) and in control group (saline solution subdermic), in the seventh day after McFarlane skin flap.

\begin{tabular}{lccccc}
\hline & \multicolumn{2}{c}{ Study Group } & \multicolumn{2}{c}{ Control Group } & $\mathrm{p}$ \\
& Mean $\pm \mathrm{SD}$ & $\begin{array}{c}\text { Median } \\
\text { (minimum-maximum) }\end{array}$ & Mean $\pm \mathrm{SD}$ & $\begin{array}{c}\text { Median } \\
\text { (minimum - maximun })\end{array}$ & \\
\hline Necrotic Area & $12.85 \pm 1.26$ & 12.76 & $10.28 \pm 1.97$ & 10.09 & 0.003 \\
& & $(10.79-14.72)$ & & $(7.68-14.23)$ & \\
Ischemic Area & $0.40 \pm 0.91$ & 0.00 & $0.86 \pm 2.15$ & 0.00 & 0.861 \\
& & $(0.00-2.71)$ & & $(0.00-6.75)$ & \\
Area of Tissular & $2.48 \pm 1.63$ & 2.50 & $3.72 \pm 2.41$ & 3.65 & 0.063 \\
Viabilility & & $(0.00-5.80)$ & & $(0.00-8.19)$ & \\
\hline
\end{tabular}


There was contraction of the final areas of the flap, when compared to the initial size $\left(21 \mathrm{~cm}^{2}\right)$ in all animals. However, there was not a significant difference when both groups where compared. Macroscopically, there was no significant difference in the percentage of the areas of necrosis, ischemia and tissular viability when both groups were compared.

On the proximal and medium thirds of the flaps, there was no difference between groups as to granulation, granulation associated with polymorphonuclears and granulation associated with necrosis (Figure 4). On the distal third, however, there was a tendency to develop less granulation tissue in flaps treated with sildenafil (Table 2).

TABLE 2 - Absolute number of granulation cases, granulation associated with necrosis or granulation associated with polymorphonuclears in biopsies collected on the seventh postoperative day, on the proximal, medium and distal thirds of the McFarlane flap, after sildenafil injection (Study Group) or saline solution (Control Group) subdermally.

\begin{tabular}{cccccccc}
$\begin{array}{c}\text { Parameter } \\
\text { Evaluated }\end{array}$ & $\begin{array}{c}\text { Proximal } \\
\text { Third }\end{array}$ & $\begin{array}{c}\text { Median } \\
\text { Third }\end{array}$ & $\begin{array}{c}\text { Distal } \\
\text { Third }\end{array}$ & $\mathrm{p}$ \\
Group & SG & CG & SG & CG & SG & CG & \\
Granulation & 8 & 10 & 4 & 8 & $1^{*}$ & $6^{*}$ & $* 0,057$ \\
Gr/Nc & 1 & 0 & 1 & 0 & 0 & 0 & \\
Gr/PMNs & 1 & 0 & 2 & 2 & 3 & 4 & \\
\hline
\end{tabular}

Granulation associated with necrosis $(\mathrm{Gr} / \mathrm{Nc})$

Granulation associated with polymorphonuclears (Gr/PMNs)

Study Group (SG)

Control Group (CG)

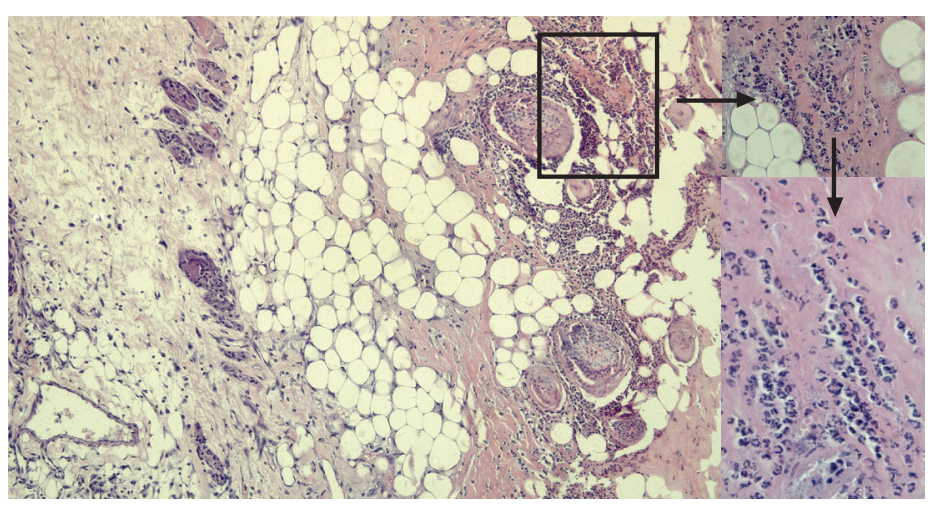

FIGURE 4 - Photomicrograph of histological skin section. Note the presence of granulation, vascular formation and edema. HE 100X. Above, a high-magnification view of the squared box showing polymorphonuclears. HE 200X. Below, the polymorphoneclears cells in a magnification of $400 \mathrm{X}$.

\section{Discussion}

The viability of skin flaps is important to reconstructive surgeries as well as aesthetic procedures. The rate of success of these surgeries is intrinsically linked to their proper planning and technical execution. Also, several studies have been carried out to analyze factors that interfere in flaps vascular supply and to propose substances that might enhance their viability ${ }^{1-11}$.

Hart et al. $^{8}$ observed a decrease in the necrotic and ischemic areas associated with intraperitoneal use of $9 \mathrm{mg} / \mathrm{kg}$ of sildenafil in daily applications, more markedly on the first and third rather than on the fifth and seventh postoperative days. Ayyildiz et $a .^{7}$ has used daily doses of $1 \mathrm{mg} / \mathrm{kg}$ of the substance orally or $0.5 \mathrm{mg} / \mathrm{kg}$ applied to a subdermal pouch below the flap, and observed a better vascularization on the seventh day. Sarifakioglu et al. ${ }^{9}$ also used sildenafil in oral daily doses of $3 \mathrm{mg} / \mathrm{Kg}, 10 \mathrm{mg} /$ $\mathrm{Kg}$ and $20 \mathrm{mg} / \mathrm{Kg}$, with good viability of the dorsal skin flaps with caudal basis in rats. Tsai et al. ${ }^{10}$ used intraperitoneal sildenafil, 10 $\mathrm{mg} / \mathrm{Kg}$ /day, associated or not with the vascular endothelial growth factor subdermally, with a reduction of the non-vascularized areas in the group treated only with sildenafil. Ulusoy et al. ${ }^{11}$ also had good results with the topical application of $10 \mathrm{mg}$ of sildenafil with fibrin glue. As can be realized, previous studies have not been unanimous as to the dosage of sildenafil citrate. Our adoption of the dosage of $0.5 \mathrm{mg} / \mathrm{Kg}$ was initially based on the research of Ayyildiz et $a l^{7}$, which also applied it subdermally and was not increased due to the systemic response leading to the death of three animals in the study group.

Even though Tsai et al. ${ }^{10}$ applied sildenafil by the intraperitoneal pathway daily, the subdermal use of the growth factor was done only once, right after the skin flap was made. Conversely, Ayyildiz et $a .^{7}$ reported the daily use of sildenafil subdermally, even though the type of restraint was not described. Obviously, the oral and intraperitoneal administrations of sildenafil do not require previous sedation. However, there were technical difficulties, as to tissue resistance and animal movement for subdermal application, and the animals had to be sedated. Due to the sympatholytic effects of xylazine, sildenafil was not used daily so as not to potentialize systemic vasodilatation and lead to death $^{14}$.

Subdermal application was adopted because it would possibly reduce the systemic effects, which are commonly observed when sildenafil is administered orally or intraperitoneally ${ }^{12}$. However, these effects could not be prevented, and three animals of the study group suffered from unresponsive cardiorespiratory arrest. 
Macroscopically, sildenafil applied subdermally was associated with higher absolute values of necrotic areas, contrasting with a previous study ${ }^{7}$. However, Ayyildiz et al. ${ }^{7}$ assessed the topic application of the substance in a single point of the caudal skin flaps, whose vascular supply comes from the deep circumflex iliac arteries ${ }^{15}$. Since axial flaps have a greater vascular perfusion pressure, sildenafil may present adequate seric concentrations in distal extremities of these flaps, stimulating vascular neoformation and tissue viability. On the other hand, even though sildenafil was more evenly distributed in different points of the flaps in the present study, its effect might have been hindered by a weak vascular system, which was incapable of maintaining constant its concentration, and of supporting growth mediators during the repair process. This assumption can be corroborated by Ulusoy et $a l .{ }^{11}$, who described smaller necrotic areas in random flaps of rats treated with sildenafil and fibrin glue, probably due to an ability to keep more constant the active substance concentration in the damaged area, aided by the fibrin.

The microscopic analysis of the distal thirds showed a tendency to less granulation in animals that received sildenafil subdermally when compared to the control group. This clinical tendency probably does not have statistical correspondence due to the sample size.

Since the use of sildenafil subdermally has resulted in greater necrotic areas under macroscopic analysis, and less granulation tissue in the distal third, other studies would confirm whether the precipitation of the active ingredient is responsible for lesser viability of the flaps. Further studies assessing sildenafil in association with a topical substance are necessary, in order to create a mesh for cellular and wound healing mediators, such as fibrin glue used by Ulusoy et al. ${ }^{11}$

\section{Conclusion}

The subdermal use of sildenafil was associated with a lower viability of the random skin flaps in rats.

\section{References}

1. Payement G, Cariou JL, Arcila M, Arrouvel C, Banzet P. Arterial phenomenon of autonomization of vascularized island flaps reviewed by expansion of the vascular pedicle. An experimental study in the rat. Ann Chir Plast Esthet. 1994;39(6):779-84.

2. Davis RE, Cohen JI, Robinson JE, Urben SL, Cook TA. Ketorolac (Toradol) and acute random-pattern skin flap survival in rat. Arch
Otolaryngol Head Neck Surg. 1995;121(6):673-7.

3. Kargi E, Deren O, Babuccu O, Hosnuter M, Erdogan B. Dual synergistic effect: the effect of dexamethasone plus carnitine on skin flap survival. Ann Plast Surg. 2004;53(5):488-91.

4. Thackham JA, McElwain DL, Long RJ. The use of hyperbaric oxygen therapy to treat chronic wounds: A review. Wound Repair Regen. 2008;16(3):321-30.

5. Isken T, Serdaroglu I, Ozgentas E. The effects of the pentoxifylline on survival of the skin flaps in streptozotocin-diabetic rats. Ann Plast Surg. 2009;62(4):446-50.

6. Mauad RJ Jr, Shimizu MH, Mauad T, de Tolosa EM. Buflomedil and pentoxifylline in the viability of dorsal cutaneous flaps of rats treated with nicotine. J Plast Reconstr Aesthet Surg. 2006;59:38792.

7. Ayyildiz A, Uysal A, Koçer U, Karaaslan O, Huri E, Germiyanoglu C, Caydere M. Effect of sildenafil citrate on viability of flaps: an experimental study in rats. Scand J Plast Reconstr Surg Hand Surg. 2005;39(4):204-8.

8. Hart K, Baur D, Hodam J, Lesoon-Wood L, Parham M, Keith K, Vazquez R, Ager E, Pizarro J. Short- and long-term effects of sildenafil on skin flap survival in rats. Laringoscope. 2006;116(4):522-8.

9. Sarifakioglu N, Gokrem S, Ates L, Akbuga UB, Aslan G. The influence of sildenafil on random skin flap survival in rats: an experimental study. Br J Plast Surg. 2004;57:769-72.

10. Tsai JW, Ayubi FS, Hart KL, Baur DA, Parham MA, Moon JK, Vazquez R, Chasen AB, Zhang Z, Pizarro JM. Evaluation of the effect of sildenafil and vascular endothelium growth factor combination treatment on skin flap survival in rats. Aesthetic Plast Surg. 2008;32(4):624-31.

11. Ulusoy MG, Uysal A, Koçer U, Karaaslan O, Cruzdan SS, Ayyildiz A, Ustün H. Improved flap viability with site-specific delivery of sildenafil citrate using fibrin glue. Ann Plast Surg. 2005;55(3):2926.

12. Uthayathas S, Karuppagounder SS, Thrash BM, Parameshwaran K, Suppiramaniam V, Dhanasekaran M. Versatile effects of sildenafil: recent pharmacological applications. Pharmacol Reps. 2007;59:15063.

13. McFarlane, Deyoung G, Henry RA. The design of a pedicle flap in the rat to study necrosis and its prevention. Plast Reconstr Surg. 1965;35(2):177-82.

14. Pereira DA, Marques JA. Uso de morfina, xilazina e meloxican para o controle da dor pós-operatória em cadelas submetidas à ovariossalpingo-histerectomia. Arq Bras Med Vet Zootec. 2009;61(2):353-61. 
15. Minh TC, Ichioka S, Harii K, Shibata M, Ando J, Nakatsuka T.

Dorsal bipedicled island skin flap: a new flap model in mice. Scand

J Plast Reconstr Surg Hand Surg. 2002;36(5):262-7.

\section{Correspondence:}

Sumara Marques Barral

R. Professor Moraes, 476/1603, Funcionários

30150-370 Belo Horizonte - MG Brasil

Tel/Fax: (55-31)3223-7710

sumara@terra.com.br
Conflict of interest: none

Financial source: none

Received: December 14, 2010

Review: February 15, 2011

Accepted: March 16, 2011 